\title{
HERMENÊUTICA FILOSÓFICA E OS FUNDAMENTOS MORAIS DA ORDEM CONSTITUCIONAL NO ESTADO DEMOCRÁTICO DE DIREITO
}

\author{
Sandro Alex de Souza Simões ${ }^{1}$ \\ Diego Fonseca Mascarenhas ${ }^{2}$
}

\begin{abstract}
Resumo
Análise jurisprudencial, a partir dos referenciais da hermenêutica filosófica, do conceito de bem comum a partir dos julgados proferidos pelo STF, para que seja desvelado quais são os Fundamentos da Ordem Constitucional no Estado Democrático de Direito, segundo entendimento da Corte Constitucional brasileira. Examina-se os escritos contidos na obra do Verdade e Método e também nos escritos posteriores ao Verdade e Método de Gadamer e investiga-se o conceito de bem comum a partir de São Tomás de Aquino e John Finnis. Por fim, analisa-se os pressupostos da teoria dos conceitos envolvidos na discussão hermenêutica, a saber, nominalismo, construtivismo, realismo e idealismo. A problematização da interpretação enquanto técnica lógico-subsuntiva é realizada ao assinalar-se que é fundamental para a hermenêutica a compreensão de certos elementos como a historicidade, a temporalidade e os preconceitos para que seja constituída a condição de possibilidade para o diálogo intersubjetivo entre o intérprete e a Constituição. Assim, busca-se reinserir na interpretação constitucional elementos éticos-valorativos, mas demonstrando que a hermenêutica filosófica é capaz de fornecer referências sólidas que não apelem ao relativismo e ao solipsismo do intérprete.
\end{abstract}

Palavras-Chave: Hermenêutica; Bem Comum; Ordem Constitucional; Estado Democrático de Direito; Direito natural; Positivismo jurídico; Jurisprudência.

\section{INTRODUÇÃO}

O objeto de estudo do artigo é centrado na análise jurisprudencial com reflexões filosóficas do conceito de bem comum a partir de julgados paradigmáticos proferidos pelo STF, a partir da hipótese de que a hermenêutica filosófica é capaz de oferecer uma leitura ética adequada ao modelo constitucional brasileiro.

A pesquisa é a análise qualitativa dos dados das decisões do STF, organizando-os em padrões que impliquem no conceito de bem comum, a partir da referência normativa do preâmbulo da Constituição, do art.5\% do LINDB e do art. 32.2 do Pacto de São José da Costa Rica; interpretação envolve a atribuição de significado à

\footnotetext{
${ }^{1}$ Pós-doutorando na Faculdade de Direito da Universidade de Lisboa. Professor no Programa de Pós-Graduação Stricto Sensu do CESUPA. E-mail: prof.sandroalex@gmail.com

Título e Resumo

${ }^{2}$ Doutorando em Direito na Universidade Federal do Pará (UFPa). Professor na DeVrey|FACI e no CESUPA. E-mail: diegomask_85@hotmail.com
} 
análise, explicando os padrões encontrados e procurando por relacionamentos entre as dimensões descritivas (PATTON, 1980).

Após um cuidadoso arrolamento bibliográfico, definimos referências que são pertinentes acerca do tema tratado neste projeto a partir de artigos e de livros publicados na forma eletrônica ou na versão impressa.

Neste estudo utilizaremos a pesquisa documental do conceito de bem comum na jurisprudência do STF, com o intuito de debater quais são os Fundamentos da Ordem Constitucional no Estado Democrático de Direito.

Por este motivo, será feita a análise bibliográfica em torno da reconstrução histórica do conceito de bem comum que se tornou empoeirada na cientificidade do positivo jurídico. Aqui, não se trata de afastar o método como se fosse uma ciência teórica inaplicável para o Direito, mas de redimensioná-lo com a virtude (areté) relacionada com a razão prática. Interessante, a saber, é a promoção do debate no campo moral e democrático na perspectiva da ética voltada para a Constituição, como elemento base da consubstanciação do Estado Democrático de Direito na aplicação do legalismo jurídico.

Inicialmente, no primeiro tópico, requer assinalar breve contextualização da atualidade do debate jurídico que se encontra inserido no Estado Democrático de Direito. Neste soa como sendo algo absurdo remeter a perspectiva do positivismo jurídico concebido no século XX, o qual tem como seu principal representante continental a Teoria Pura de Hans Kelsen. Este modelo de legalismo sofreu duras críticas por desconectar a ética com o Direito, afastando-o da realidade das operações do direito e da justiça, das quais não se separa a avaliação das repercussões e dos fins morais das ações. Em virtude disto, emergiu no pensamento jurídico atual a análise do fundamento ético da ordem constitucional.

O objetivo deste tópico é de desvelar qual é o fundamento moral da ordem Constitucional na fundamentação das decisões que utilizam como parâmetro ético o preâmbulo da Constituição, o art. $5^{\circ}$ do LINDB e o art. 32.2 do Pacto de José da Costa Rica, haja vista que esses três elementos normativos aduzem referências ao conceito de bem comum na promoção no desenvolvimento dos Direitos Humanos. Daí foram escolhidas três decisões mais recente no STF, no âmbito do controle concentrado de constitucionalidade, com larga preocupação acerca de uma repercussão prospectiva na sociedade brasileira, sendo aptas ao estudo pretendido. Assim, na ADPF 132 possibilitou a união estável de pessoas do mesmo sexo; na ADPF 130 suspendeu-se a eficácia da lei de imprensa a fim de que fosse preservada a liberdade de expressão no Estado Democrático de Direito; na ADIn 3.510 permitiu o estudo de células-tronco para fins terapêuticos e na ADIn 3.330 assinalou a implementação da política pública do acesso da universidade para todos (PROUNI).

O segundo tópico, requer uma pesquisa bibliográfica capaz de reler aspectos importantes da grande tradição filosófica, reinterpretando-a para que dialogue com os problemas do Direto contemporâneo. Nesse 
sentido, utilizamos o significado de filosofia prática ou ciência política com conceito de prudência (phrónesis) segundo Aristóteles, no entanto o pensamento aristotélico interliga os dois conceitos no sentido de que ambos só podem ser analisados se for em conjunto, em razão de haver entre estes grandes complementariedades de sentido. Por sua vez, essa é a tarefa que Gadamer, ao recepcionar o pensamento aristotélico a hermenêutica filosófica, realiza ao unir de vez o significado entre filosofia prática e phrónesis.

Ora, seria uma análise incompleta do conceito de prudência (phrónesis) de Aristóteles se fosse desconsiderado o seu fundamento político, sobretudo no estudo dos escritos posteriores ao Verdade e Método. Por fim, será abordado o conceito de bem comum em São Tomás de Aquino e o pensador tomista John Finnis, haja vista que o primeiro pensador que recepciona este significado a partir de Aristóteles como elemento integrante da política, bem como Finnis, representante da tradição do direito natural tomista na filosofia do direito contemporâneo, confere ao bem comum sua formulação analítica na estrutura de seus bens básicos ou primários. A finalidade desta análise é de abrir as portas do Direito com o diálogo ético em decisões judiciais no Estado Democrático de Direito.

No terceiro tópico, será confrontada a hipótese se a hermenêutica jurídica é capaz de realizar a leitura ética da Constituição por meio da análise do conceito de bem comum. Para isto implica responder os seguintes questionamentos: a hermenêutica filosófica é uma hermenêutica normativista, ou seja, se a sua ética assume que há leis naturais que vinculam o agir? Ou se a hermenêutica filosófica é construtivista a partir da phrónesis dirigida para o agir individual no sentido de uma ética mais individual baseado em casos específicos?

Por fim, se há o diálogo ou a incompatibilidade entre Gadamer e São Tomás de Aquino, em razão daquela negação da possibilidade de haver uma ética formal de caráter normativista, enquanto este se baseia por meio de uma ética normativismo em virtude de defender a existência de leis naturais? Em outros termos, qual é a relação entre bem comum e Lei Natural? É possível pensar numa lei natural dentro da hermenêutica filosófica ou a ética de Gadamer é uma ética mais das virtudes ou, melhor, mais baseada nos valores do que em leis propriamente dita?

\section{O BEM COMUM COMO FUNDAMENTO MORAL DA ORDEM CONSTITUCIONAL NA FUNDAMENTAÇÃO DAS DECISÕES}

A percepção de que a hermenêutica é um elemento que pode servir para realizar uma leitura moral da Constituição brasileira, procurando revelar quais são os fundamentos da sua ordem constitucional como base ética e valorativa do Estado Democrático de Direito.

Trata-se de uma leitura dos fundamentos morais da política na perspectiva de unir a hermenêutica à 
ética ${ }^{3}$. Tarefa que requer considerar a existência de agentes morais capazes de deliberação, como na análise valorativa por parte da magistratura sobretudo a parte do preâmbulo da Constituição ${ }^{4}, \mathrm{o}$ art. $5^{\circ}$ do $\operatorname{LINDB}^{5}$ e o art. 32.2 do Pacto de São José da Costa Rica $^{6}$ em que o Brasil é signatário no plano da proteção dos Direitos Humanos, tendo em vista que, todos, assinalam referência normativa da promoção do bem comum como valor ético.

A leitura, da Carta Maior é a busca dos fundamentos da ordem jurídica nacional propriamente dita e, tendo em vista que o ordenamento legislativo apresenta desgaste quando assinalamos a necessidade de acomodar as diferentes leituras que a Constituição permite, tal esforço demonstra ser indispensável para a estabilização do direito através de sua interpretação e aplicação.

$\mathrm{Na}$ atualidade, a pretensa função "ordenadora" não pode privar-se de um produtivo diálogo com o direito positivo (válido), com as realidades da sociedade tecnocientífica e com a dimensão democrática do direito que deve caracterizar o projeto jurídico moderno, como pretende a Constituição de 1988. A incorporação na reflexão jurídica de dimensões políticas possibilita o rompimento com o paradigma reducionista e dogmático do positivismo jurídico (BARRETTO, 2013, p. 100).

Ora, interpretar não implica ser um ato estritamente subsuntivo, mas necessariamente em opções políticas e de uma leitura da sociedade, como podemos notar no fenômeno, que era desconhecido historicamente no Brasil, da judicialização da política ${ }^{7}$. Nessa podemos observar que há uma incessante procura de adequação e os papéis que cada Poder possui dentro de um novo Estado Democrático de Direito. Esse é um exemplo de um debate atual em torno de elementos que estão na ordem constitucional sem necessariamente encontrarem-se expressos ou normatizados, em sentido estrito, o que explica a corrente de neoconstitucionalismo no Brasil - e mesmo na América latina - à caça dos princípios constitucionais, mas refere ao mesmo tempo que a questão está

\footnotetext{
${ }^{3}$ Os escritos posteriores, de Gadamer, a obra Verdade e Método, vol. II, elucida os pontos do pensamento do autor no que diz respeito a reflexão da hermenêutica voltada para a questão ética quando aponta que "o tu busca o encontro do Outro para, dessa forma, o indivíduo consiga estar consigo mesmo; e, o homem por ser parte integrante da história, habilita-o a se projetar nesta mediante consciência dos efeitos históricos, para que seja cumprida as promessas de amizade na constituição de laços de solidariedade a partir dos direitos edificados na comunidade".

${ }^{4}$ Constituição Federal de 1988. Preâmbulo: nós, representantes do povo brasileiro, reunidos em Assembleia Nacional Constituinte para instituir um Estado Democrático, destinado a assegurar o exercício dos direitos sociais e individuais, a liberdade, a segurança, $O$ bem-estar; o desenvolvimento, a igualdade e justiça como valores supremos de uma sociedade fraterna, pluralista e sem preconceitos, fundada na harmonia social e comprometida, na ordem interna e internacional, com a solução pacífica das controvérsias, promulgamos, sob a proteção de Deus, a seguinte Constituição da República Federativa do Brasil (grifo nosso).

${ }^{5}$ Art. $5^{\circ}$ do LINDB - Na aplicação da lei, o juiz atenderá aos fins sociais a que ela se dirige e às exigências do bem comum (grifo nosso).

${ }^{6}$ Pacto do São José da Costa Rica. Art. 32 - Correlação entre deveres e direitos: 2 - Os direitos de cada pessoa são limitados pelos direitos do demais, pela segurança de todos e pelas justas exigências do bem comum, em uma sociedade democrática (grifo nosso).

${ }^{7}$ No artigo titulado Judicialização das políticas públicas e sua Ilegitimidade é conceituado o termo judicialização da política no seguinte trecho: é o caso do uso de argumentos políticos, como os de impacto e repercussão, e das decisões que fiscalizam, restringem ou substituem as ações típicas dos outros poderes, como é o caso na judicialização da política. Aqui não se trata apenas
} 
além dos princípios, senão nos fundamentos da ordem constitucional.

Assim, os princípios estão fortemente enraizados na estrutura normativa, mas, por sua vez, eles demandam a necessidade do desvelamento. De onde derivam esses princípios? Existe alguma coisa entre eles e a ordem normativa que seja capaz de manter uma coesão entre ambos? Esses fundamentos são elementos necessários para que nós entendamos o próprio Estado Democrático de Direito como um valor?

O estado democrático de direito pressupõe para a realização dos objetivos estabelecidos na constituição, uma leitura específica do sistema jurídico. A hermenêutica constitucional irá buscar os seus fundamentos para além da estrutura positivada do direito, nas raízes ético-filosóficas do estado, do direito e do valor mais alto da ordem jurídica que é a justiça. Pretendemos, assim, estabelecer as relações necessárias entre a natureza éticopolítica do estado democrático de direito e sua sistematização jurídica, consagrada na constituição (BARRETTO, 2007, p. 319-320).

Partimos da consideração de que vivemos num Estado em que o elemento central é composto por agentes morais capazes de deliberação. Pois bem, tal informação implica em dizer que se trata de uma posição necessariamente valorativa considerar que o cidadão é capaz de decidir diante de várias possibilidades distintas de leitura moral da Constituição. A própria dinâmica do processo político, seja eleitoral, seja legislativo, seja a manifestação mais direta das opiniões de rua, demonstra que as posições se formam a partir de em torno de valores e ideais, não lei ou os mecanismos de sua interpretação e aplicação.

Os problemas com que se defrontam os tribunais, em alguns países de modo mais evidente do que em outros, fazem com que os juízes, principalmente as Cortes Constitucionais, como o Supremo Tribunal Federal (STF) brasileiro, tenha que decidir, não somente, e principalmente, em função das determinações da lei positiva, mas em relação a interlocutores que são responsáveis, portanto agentes morais que atuam como autores e destinatários de direitos. A decisão judicial no quadro do estado democrático de direito, cuja ordem jurídica resulta da vontade de agentes morais, pressupõe uma fundamentação necessariamente. Quando os juízes tomam posição em relação ao aborto, à eutanásia, aos direitos das minorias e outros temas, eles não oferecem uma solução definitiva para essas questões, mas sim como partícipes e interlocutores privilegiados no debate moral e jurídico que se processa no espaço público (BARRETTO, 2012, p. 5936).

Ora, não é por causa da definitividade da decisão que os juízes como interlocutores privilegiados dos julgados chamam a atenção da comunidade, mas em razão da natureza de um processo dentro do Estado Democrático de Direito que se encontra marcado por posições a partir das quais as referências valorativas funcionaram não só para a qualificação do debate e também para a inclusão de pessoas como agentes morais para

de ter que decidir para além das regras, mas de ser chamado a decidir sobre interesses e prioridades da sociedade como um todo (MASCARENHAS, 2009, p.147). 
dentro do processo deliberativo no espaço público.

A compreensão é processada com vistas à aplicação, na medida em que a resposta se encontra no enunciado, ao qual a questão (pergunta) deverá ser formulada. Não se trata, portanto, de um simples processo de interpretação, com o estabelecimento do sentido e alcance nos moldes entendidos pelas hermenêutica tradicional. Pelo contrário, a compreensão está conectada à interpretação, justificando a pergunta formulada, alicerçada, por sua vez, numa série de fatores prévios, que tomam em conta as variadas características da situação concreta. Sendo que nessas conexões torna-se fundamental o papel da phrónesis ou saber ético (ENGELMANN, 2007, p. 129). Nessa perspectiva Gadamer assinalou:

Ou melhor, interpreta os enunciados como respostas a perguntas que tem de compreender (...) todo enunciado deve ser considerado como uma resposta a uma pergunta e que a única via para entendê-lo consiste em fazer a pergunta da qual esse enunciado é uma resposta. Essa questão prévia tem sua própria direção de sentido e não pode ser formulada a partir de uma trama de motivações situadas em segundo plano, mas com o auxílio de outros contextos de sentido abrangidos pela pergunta e esboçados no enunciado (GADAMER, 2004).

Notamos que em casos paradigmáticos o STF buscou motivar a sua fundamentação jurídica a partir do conceito de bem comum ou de uma definição ética do que seja o bem comum a ser alcançado naqueles temas. Assim selecionamos a ação de descumprimento de preceito fundamental (ADPF) 132, que possibilitou a união estável de pessoas do mesmo sexo; a ADPF 130, que suspendeu a eficácia da lei de imprensa a fim de que fosse preservada a liberdade de expressão no Estado Democrático de Direito; na ação direta de inconstitucionalidade (ADIn) 3.510, a qual permitiu o estudo de células-tronco para fins terapêuticos pela definição do que seriam "embriões viáveis" na lei de biossegurança e a ADIn 3.330, que assinalou a implementação da política pública do acesso da universidade para todos (PROUNI). Desse modo, reiteramos que todas estas decisões polêmicas e controvertidas têm em comum é de estabelecer o diálogo entre o Direito, a Hermenêutica e a Ética por meio do conceito de bem comum.

No julgamento da ADPF 132 que versou em torno da possibilidade legal da união estável entre casais homoafetivos, o voto do Ministro relator Carlos Ayres Britto claramente foi valorativo. O magistrado em vários momentos argumentou que não se pode admitir uma leitura da constituição que não consagre a isonomia entre as pessoas, e o definidor dessa igualdade foi a consideração de que somos igualmente capazes de decidir o que the é o bem.

Prossigo para ajuizar que esse primeiro trato normativo da matéria já antecipa que o sexo das pessoas, salvo expressa disposição constitucional em contrário, não se presta como fator de desigualação jurídica. É como dizer: o que se tem no dispositivo constitucional aqui reproduzido em nota de rodapé (inciso IV do art $3^{\circ}$ ) é a explícita vedação de tratamento discriminatório ou preconceituoso em razão do sexo dos seres humanos. Tratamento discriminatório ou desigualitário sem causa que, se intentado pelo comum das pessoas ou pelo próprio Estado, passa a colidir frontalmente com o objetivo constitucional de "promover o bem de todos" (este o explícito objetivo que se lê no inciso em foco) (STF, ADPF 132/RJ. Voto Min. rel. Carlos Ayres Britto, p.7. DJ 14/10/2011). 
"Bem de todos", portanto, constitucionalmente versado como uma situação jurídica ativa a que se chega pela eliminação do preconceito de sexo. Se se prefere, "bem de todos" enquanto valor objetivamente posto pela Constituição para dar sentido e propósito ainda mais adensados à vida de cada ser humano em particular, com reflexos positivos no equilíbrio da sociedade. $\mathrm{O}$ que já nos remete para o preâmbulo da nossa Lei Fundamental, (...). Tipo de constitucionalismo, esse, o fraternal, que se volta para a integração comunitária das pessoas (não exatamente para a "inclusão social"), a se viabilizar pela imperiosa adoção de políticas públicas afirmativas da fundamental igualdade civil-moral (mais do que simplesmente econômico-social) dos estratos sociais historicamente desfavorecidos e até vilipendiados. Estratos ou segmentos sociais como, por ilustração, o dos negros, o dos índios, o das mulheres, o dos portadores de deficiência física e/ou mental e o daqueles que, mais recentemente, deixaram de ser referidos como "homossexuais" para ser identificados pelo nome de "homoafetivos". Isto de parelha com leis e políticas públicas de cerrado combate ao preconceito, a significar, em última análise, a plena aceitação e subsequente experimentação do pluralismo sócio-político-cultural. Que é um dos explícitos valores do mesmo preâmbulo da nossa Constituição e um dos fundamentos da República Federativa do Brasil (inciso V do art. $1^{\circ}$ ). Mais ainda, pluralismo que serve de elemento conceitual da própria democracia material ou de substância, desde que se inclua no conceito da democracia dita substancialista a respeitosa convivência dos contrários (STF, ADPF 132/RJ. Voto Min. rel. Carlos Ayres Britto, p.7-8. DJ 14/10/2011).

Nesse caso, o art. 226 da CRFB c/c art. 1.723 do CC/02 representam ser dois institutos bastante tradicionais de longevidade ancestral dentro do sistema jurídico, que ao serem relidos a partir de um valor que funcionaram como um fundamento da decisão. E, note-se, uma decisão em sentido distinto daquilo a que tais disposições, mesmo que traduzidas por diplomas anteriores, buscavam preservar.

Podemos iluminar os efeitos deste julgado por meio da hermenêutica filosófica, pelo fato desta poder realizar a leitura da ordem constitucional comum ao texto em razão de ser escrita a partir de uma estrutura ética ${ }^{8}$ e não apenas pela estrutura normativa. Destaca-se que a pergunta que subjaz a própria questão de qual a decisão justa ou adequada ao conflito e a de saber qual o fundamento da igualdade ou quais critério podem ser legítimos e, portanto, quais não podem sê-lo, para o estabelecimento de limites ao seu exercício. Nosso ponto de afirmação no presente artigo não pretende avaliar a correção da resposta dada, portanto, não envolve que no posicionemos quanto a isso, contudo importar-nos assinalar que a decisão do STF não encontrou outro caminho senão trazer à frente, ao proscênio do debate, aquilo que entendia subjacente a ele, focando daí nos agentes morais e atores políticos, bem como nos valores que entendia defini-los na ordem democrática.

Na oportunidade da análise breve de outro julgado polêmico e controvertido, a decisão da ADPF 130 versou em torno da revogação da Lei de Imprensa por ser suscitada a sua incompatibilidade com a Constituição

\footnotetext{
${ }^{8}$ O livro intitulado Lei e Liberdade na ADPF 130: uma leitura da decisão a partir de Hannah Arendt realiza a investigação de que os juristas costumam ter concepções políticas sem se darem conta disso e, suas decisões e fundamentações costumam expressar uma ou mais concepções políticas sem que eles sintam necessidade de tornar isto explícito. Pelo contrário, a ideia de que o judiciário esteja apenas "cumprindo o direito" de modo imparcial leva muitos juízes à conclusão de que suas decisões não devem parecer ser políticas e que eles devem ocultar na maior medida possível as ideias políticas em que se baseiam seus argumentos jurídicos. Tudo precisa parecer extraído e baseado apenas no texto da Constituição, tornando difícil a tarefa de extrair com certeza as concepções políticas que sedimentaram as decisões ou o que estas expressam (MASCARENHAS, 2013, p.7).
} 
Federal. A mídia representa o mesmo fundamento plural da democracia, uma vez formadora de opinião pública ao oferecer uma alternativa à versão dos fatos. A liberdade de informação jornalística, portanto, não pode ser regulada pelo Estado. Em outro sentido, houve votos minoritários da Corte que aludiram para a influência e o poder social nefasto que a mídia, supostamente, pode exercer contra os cidadãos, isto é, apontaram para a necessidade da regulamentação legislativa da sua atividade para que a mídia exerça à completude e a fidedignidade das informações prestadas ao público por ser capaz de formular seus próprios juízos morais acerca da sua própria vida e do bem comum, como assinalado na Constituição e também no Pacto de São José da Costa Rica, este se refere especialmente ao direito de respeito.

Importam-nos mais diretamente, para os fins aqui colimados, os dispositivos constitucionais que cuidam de balancear o poder distorsivo das empresas de comunicação social sobre o discurso público, que devem ser compreendidos como intervenções pontuais que relativizam a liberdade de expressão em prol do fortalecimento do sistema de direitos fundamentais e da ordem democrática traçados em esboço na Constituição. No vértice de tal sistema se encontra a pessoa humana, como agente moral autônomo em suas esferas privada e pública, capaz de formular seus próprios juízos morais acerca da sua própria vida e do bem comum (STF, ADPF 130/DF. Min. rel. Carlos Ayres Britto. Voto Min. Celso de Mello p.188. DJ 06/09/2009).

Toda pessoa tem direito à proteção da lei contra tais ingerências ou tais ofensas' e com o artigo 32.2, segundo o qual 'Os direitos de cada pessoa são limitados pelos direitos dos demais, pela segurança de todos e pelas justas (STF, ADPF 130/DF. Min. rel. Carlos Ayres Britto. Voto Min. Celso de Mello p.192. DJ 06/09/2009).

Neste julgado, a discussão mantém-se aberta acerca da hipótese de uma Lei para a Imprensa, segundo a concepção acerca da potencialidade conflituosa entre a liberdade de imprensa e a formação da opinião pública, tendo em vista que o julgamento da ADPF 130, pela complexidade do objeto da demanda, a liberdade de expressão e da imprensa no Estado Democrático de Direito (MASCARENHAS; COSTA, 2014, p. 157-142) são elementos vitais para iluminar e manter a alteridade, o horizonte do Outro na projeção da busca do bem comum na perspectiva do diálogo que requer a pluralidade de opiniões.

Já em outra decisão, o julgado da ADIn 3.510 outro tema polêmico envolveu a constitucionalidade do art. $5^{\circ}$ da Lei de Biossegurança (Lei no 11.105/05), alegando, entre outras coisas, que haveria violação do direito à vida, vide art. 5º, caput, $\mathrm{CF} / 88$, na autorização de experiências laboratoriais com embriões humanos congelados. O que se quer mostrar é que a decisão em questão, a saber, se a proteção à vida já se aplica aos embriões humano, para além dos congelados por extensão dado que o debate importa em definir o estatuto do embrião humano, e se tal proteção deveria ou não prevalecer sobre os direitos e interesses sociais associadas à pesquisa com célulastronco embrionárias (MASCARENHAS, 2011b, p.366).

Avanço no raciocínio para assentar que essa reserva de personalidade civil ou biográfica para o nativivo em nada se contrapõe aos comandos da Constituição. É que a nossa Magna Carta não diz quando começa a vida humana. Não dispõe sobre nenhuma das formas de vida humana pré-natal. Quando fala da 'dignidade da pessoa humana' (inciso III do art. $1^{\circ}$ ), é da pessoa humana naquele sentido ao mesmo tempo notarial, biográfico, moral e espiritual (o 
Estado é confessionalmente leigo, sem dúvida, mas há referência textual à figura de Deus no preâmbulo dela mesma, Constituição). E quando se reporta a 'direitos da pessoa humana' (alínea b do inciso VII do art. 34), livre exercício dos direitos (...) individuais' (inciso III do art. 85) e até dos 'direitos e garantias individuais' como cláusula pétrea (inciso IV do $\$ 4^{\circ}$ do art. 60), está falando de direitos e garantias do indivíduo-pessoa (STF, ADIn 3.510/DF. Voto Min. rel. Carlos Ayres Britto, p. 164. DJ 28/05/2010).

Enfim, esses são apenas alguns exemplos, colhidos do direito comparado, que demonstram a preocupação dos países europeus com a pesquisa envolvendo células-tronco embrionárias. Vê-se que as legislações estrangeiras têm ao menos três pontos em comum: o primeiro referente à obrigatoriedade de que os embriões sejam utilizados em pesquisas que visem ao bem-comum; o segundo, que sejam utilizados apenas embriões excedentes dos processos de fertilização in vitro, o que, em outras palavras, significa a proibição de que sejam criados embriões para este fim; e, por último, que haja o consentimento expresso dos genitores (STF, ADIn 3.510/DF. Min. rel. Carlos Ayres Britto. Voto Min Joaquim Barbosa, p.472. DJ 28/05/2010).

A determinação do início da tutela jurisdicional à vida humana é uma questão não definida na Constituição Federal brasileira e, de resto, maior parte das Constituições do mundo ocidental, pelo motivo de ser uma questão deliberativa no plano jurídico voltando-se a sua fundamentação para o aspecto ético-político por refletir valores morais fundantes do bem comum no Estado Democrático de Direito.

No caso em tela, sintomaticamente, uma questão hermenêutica marcante é revelada, qual seja, a de saber se era necessário que a Constituição Federal cuidasse expressamente do embrião referindo-se a ele como detentor da proteção atribuída a pessoa humana por nascimento ou e tal garantia já estava pressuposta na própria definição do direito à vida. Em grande parte, a hermenêutica trata do reino do pressupostos e premissas, daquilo que não se vê, mas que conduz a decisões e formas de mundo com que lidamos. Aquilo que subjaz nas tomadas de decisões do Tribunais, especialmente.

Por sua vez, as pesquisas com o embrião humano congelado apontam para o desenvolvimento científico no ramo da medicina, com o fulcro de ampliar as fronteiras de possibilidades da saúde pública (MASCARENHAS, 201 la, p.1) são um dos temas da atualidade que remetem constantemente para além deles mesmos, senão para as definições fundamentais acerca do valor das escolhas humanas em sociedade tecnológica, na qual não são nítidas ou auto evidentes as fronteiras entre o poder-fazer e o dever-fazer.

Dessa maneira, o iter percorrido pelo voto vencedor acima colacionado demonstra a absoluta insuficiência da metodologia formal e subsuntiva, com esteio nas fórmulas e fatos, para dar conta da tarefa de decisão. As referências legais acabam por dizer menos, muito menos, porque não dizem o fundamental e demonstram o argumento central do nosso artigo, qual seja, que o silêncio, a mudez diante dos problemas de fundamento pronunciam eloquentemente que nas sociedades contemporâneas complexas, é inevitável que sejam revisitadas as escolhas anteriormente feitas, trazido novamente à tona os sujeitos, os agentes morais que tomaram, ou os que as assumem segundo a responsabilidade política metageracional das democracias representativas, bem como os valores que as presidiram. 
Em outra perspectiva de jurisprudência, o STF se pronunciou na decisão da ADIn 3.330 que versou sobre a isonomia na ação afirmativa do programa universidade para todos (PROUNI).

Senhor Presidente, eu, preliminarmente, gostaria de parafraseá-lo, de alguma sorte, nessa
questão, quando Vossa Excelência afirma que há determinados processos que tramitam aqui
no Supremo Tribunal Federal, que são auto evidentes quanto à sua constitucionalidade.
Uma Constituição Federal que traz, no seu preâmbulo, a promessa de construção de uma
sociedade justa, solidária, com erradicação de desigualdades, não pode ser fundamento para
se declarar inconstitucional um programa político, editado pelo Poder Público, que visa o
acesso de todos ao ensino universitário. Evidentemente que mesmo uma eventual
confrontação - absolutamente desproporcional e desigual - entre esse valor, que representa
o próprio fundamento do Estado Democrático de Direito brasileiro - a criação dessa
sociedade idealizada -, evidentemente que o princípio da livre iniciativa sucumbiria
fatalmente numa ponderação de valores, qualquer que seja a doutrina adotada pelo prolator
do voto (STF, ADIn 3.330/DF. Min. rel. Carlos Ayres Britto. Voto Min. Luiz Fux, p.58. DJ
03/05/2012).

O ministro Luiz Fux no seu voto fez referência expressa a parte de caráter moral do preâmbulo da Constituição ao apontar que neste está contido o próprio fundamento do Estado Democrático de Direito, pois, em geral, os preâmbulos constitucionais valem como princípios e não como normas jurídicas (JACQUES, 1957). Nesse contexto, o princípio da igualdade não proíbe de modo absoluto as diferenciações de tratamento. Veda apenas aquelas diferenciações arbitrárias. Assim, o princípio da igualdade no fundo comanda que só se façam distinções com critérios objetivos e racionais adequados ao fim visado pela diferenciação (FERREIRA FILHO, 2001, p. 277). Assim, fizemos notar que é controvertido o entendimento de uma parte da doutrina que aponta o preâmbulo da Constituição como não possuidor de nenhuma força normativą, excluindo-a como referência principiológica na fundamentação da decisão judicial.

Nesse sentido, o direito encontra na lei a sua normatividade, sendo normativo no sentido de que a questão dos direitos se inscreve sob a forma de um "deve ser", que nos define como autores e destinatários de direitos, como agentes morais, dotados de racionalidade e autonomia, e que nós reconhecemos intersubjetivamente (BARRETTO, 2012, p. 5936). Portanto, há um valor moral em si mesmo nos pressupostos democráticos e no projeto jurídico, quando neste se projeta a autonomia na esfera pública. Tarefa que requer desvencilhar das individualidades para contemplar o bem comum, onde todos são sujeitos de direito ao se reconhecer ao mesmo tempo como autores e destinatários das normas e das instituições.

Procurando elaborar a produção dos argumentos e das razões, como o fator principal do projeto jurídico, a filosofia do direito acompanha praticamente esse projeto, demonstrando que a racionalidade prática à qual se

\footnotetext{
${ }^{9}$ Este caráter de outrora de descaracterizar o preâmbulo da Constituição de força normativa, deve-se ao fato dos juristas costumam ter concepções políticas sem se darem conta disso e, suas decisões e fundamentações costumam expressar uma ou mais concepções políticas sem que eles sintam necessidade de tornar isto explícito. Pelo contrário, a ideia de que o judiciário esteja apenas cumprindo o direito de modo imparcial leva muitos juízes à conclusão de que suas decisões não devem parecer ser políticas e que eles devem ocultar na maior medida possível as ideias políticas em que se baseiam seus argumentos jurídicos. Tudo precisa
} 
refere o direito se encarna nos discursos públicos. Todo o processo de debate no espaço público de uma sociedade democrática ocorre através do discurso, como prática interindividual entre sujeitos de direito, e caracteriza-se por produzir argumentos e razões, submetidas ao auditório público com vistas a serem avaliadas e validadas (BARRETTO, 2007, p. 331)

Esta análise deve ser observada, sobretudo, na fundamentação da decisão judicial, pois o problema da universalidade da interpretação como problema hermenêutico reside na ontologia da linguagem. Nesse sentido, pretendemos abordar não uma hermenêutica jurídica, mas a hermenêutica filosófica que tem alcance universal, haja vista que esta tem um caráter heurístico de exploração que envolve também o Direito ao voltar a sua análise para o campo do raciocínio jurídico por meio do conceito de bem comum.

O referencial teórico da hermenêutica filosófica de Hans-Georg Gadamer por meio de seus escritos contidos da obra do Verdade e Método e também nos escritos posteriores ao Verdade e Método, interessam-nos na medida em que a discussão ética que se encontra rigorosamente conectada com filosofia política, situando-se de que esta análise se encontra no diálogo entre Aristóteles e a sua recepção em Gadamer.

A partir do exposto, como a jurisprudência pode se apropriar do conceito de bem comum nos julgados proferidos pelo STF a fim de desvelar quais são os fundamentos morais da ordem Constitucional no Estado Democrático de Direito?

\section{DIREITO E POLITICA: ABERTURA DO DIÁLOGO ÉTICO EM DECISÕES JUDICIAIS NO ESTADO DEMOCRÁTICO DE DIREITO}

As perguntas que são projetadas determinam o modo como a Constituição irá responder, então o intérprete e a Constituição entram num diálogo intermediado pela hermenêutica, que compreende a posição situacional da atividade do intérprete reflexivamente. Dessa forma, a história jurisprudencial da Constituição que é o intervalo e o interstício sem o qual não é possível realizar um salto de 1988 para os dias de hoje, tendo em mente que haverá uma história dos efeitos da norma jurídica constitucional. Ou seja, não e pode alijar do horizonte que os próprios intérpretes da Constituição estão realizando a norma constitucional sob a qual estão abrigados. Projetam-na e são projetados por ela em uma dinâmica indissociável.

Então, essa historicidade, essa recepção e a presença determinante ou condicionante do intérprete é afastada pelo positivismo, que apostasia do sujeito e objeto como se estivesse fora do cosmos se conhecendo num plano abstrato ou matemático, pois a Constituição não pode ser decida como se fosse uma solução de equação matemática onde a historicidade, condição essencial do intérprete, não seja influenciada e, ao mesmo passo não

parecer extraído e baseado apenas no texto da Constituição, tornando difícil a tarefa de extrair com certeza as concepções políticas que sedimentaram as decisões ou o que estas expressam (MASCARENHAS, 2013, p. 11). 
interferiria nos desdobramentos e sua ação. $\mathrm{O}$ aspecto singular desse fenômeno consiste em que sujeito e objeto são distintos, contudo não pode ser assumido como distantes e estanques. Ao invés disso, olhando de perto, o objeto da interpretação é elaborado em boa medida pelo próprio intérprete que sobre ele encontra-se debruçado.

O romantismo Alemão assinala que houve uma invisibilização da transição entre o pensamento medieval e a Idade Moderna, fato que transformou o Direito num elemento estritamente técnico e científico, tornando turva e reduzida a leitura jurídica dos problemas verdadeiramente humano no ato de se interpretar a Constituição.

A caminhada da escola da exegese para o legalismo não possui preocupação com a política e tampouco com a moral, afastando estes dois elementos do alcance do Direito. A principal preocupação e meta do pensamento jurídico da Europa continental dos séculos XVIII e XIX foi a de produzir uma metodologia que pudesse compreender o direito como um sistema, em tendo como modelo mimético as ciências da natureza. A objetividade, que implica necessariamente no abstracionismo das fórmulas, a compartimentalização do saber, sua especialização e assim preferirmos, assim como a progressiva tecnificação da dogmática concentrada daí mais na aplicação do aparato legislativo nascente sob a forma da novel codificação, no lugar de elaboração da leis, que passa a ser um mister mormente político deixado a um poder específico do Estado, concorrem para tal fenômeno de "invisibilização", pois o direito ou a "ciência jurídica" para constituir-se enquanto tal não pode assumir encargos que cada vez mais quedam-se no crisol da política representativa em ebulição. A legitimidade passa a ser a palavra de ordem da política, ao passo que sistema e método são as da ciência. Dessa maneira, lidar com problema realmente humano e esgotá-lo no normativismo evitando relacioná-los com a política e com a moral, faz parte necessariamente do projeto da modernidade e talvez consista em mais um dos seus fracassos.

Para refletir criticamente o positivismo jurídico, podemos analisar o aspecto da crítica estética, em razão deste ser importante para apontar a questão do julgar e também para a discussão de que há e de que sempre houve outro caminho de revelação da verdade que não é a técnica. Sendo assim, o elemento ético é essencial como elemento da hermenêutica.

É natural que no processo de tecnificação do Direito ocorra o afastamento de conceitos como razão prática e prudência (phrónesis), tendo em vista que esses elementos estão relacionados com a virtude (areté) e o positivismo jurídico se encontra relacionado como um instrumento de integração do ordenamento jurídico. Logo, esses conceitos podem ser relidos a partir da compreensão da hermenêutica fundamental de Gadamer e da historicidade do texto, pois quando é recolocado o elemento da historicidade nesse percurso, podemos perceber o que nós perdemos e o que ganhamos ao longo do caminho, ou seja, saberemos as transformações de sentido das palavras naquilo que estamos utilizando.

A hermenêutica trabalha com a ideia determinante de tradução que é a transmissão histórica da 
linguagem. Assim, tem que traduzir a Constituição mesmo que ela tenha sido escrita no vernáculo; e, a tradução é sempre uma ressignificação a partir da historicidade do intérprete cujo os horizontes se fundem com o do texto.

Não se trata de relativismo, exatamente, por conta dos preconceitos e da tradição, então o intérprete consciente adquire consciência do seu horizonte de pré-compreensão e de seus preconceitos. Nesse movimento circular de compreensão, a hermenêutica abre as portas do Direito para a ética, superando a perspectiva do positivismo baseado num modelo iluminista que visa separar e neutralizar a relação entre o Direito e a ética.

Consideramos a ideia de que a modernidade representa um corte profundo na tradição do pensamento, afirma que o corte que a modernidade realiza não alcança a concepção ontológica que tornou predominante com grande tradição (COSTA, 2008, p. 26). A hermenêutica filosófica é um elemento para desvelar a leitura de valores éticos da constituição não por uma via especulativa, mas a partir de uma racionalidade prática que necessariamente vai redundar em decisões sobre o bem agir. Nesse contexto, a prudência, na diretriz da filosofia prática, é essencialmente uma arte política para descobrir os caminhos da vida boa dentro da polis.

Desse modo, a filosofia teórica e a filosofia prática (ciência política) possuem como ponto em comum é a busca da verdade. Na filosofia teórica a verdade se apresenta na noção de fim e na filosofia prática se manifesta na relação de meio em vista de outro que participa da ação. Nota-se que a filosofia prática está atrelada com o contingente porque o seu foco se volta para o presente a partir da análise do caso concreto. Em outras palavras, a verdade é construída em razão da valorização do modo de ser do ente homem historicamente constituído.

Este raciocínio é exposto por Aristóteles para assinalar que toda intervenção humana visa a concretização do bem determinado. O pensamento aristotélico designa-se como bem supremo a busca da felicidade (eudaimonia) pela maioria dos homens, tendo em vista que os homens ao deliberar já detêm um telos previamente definido que aponta para o bem moral, pois o que pode ser alterado são os meios para alcançar o fim. Estes são passiveis de alteração, mas o fim não.

Assim é imprescindível viver, construir e interpretar as normas e os contextos que a vida apresenta a cada momento, excluindo a pretensão da resposta previamente elaborada. Evidencia-se que a phrónesis surge como uma espécie do saber prático, que aponta para prudência do homem no seu agir, cujo objetivo é a realização do seu bem. Entretanto, a phrónesis não se trata de uma concepção individualista do bem, mas sua contextualização projetada para a integralidade do homem (ENGELMAN, 2007, p. 23-25).

Dito de outro modo, a deliberação consiste em combinar meios eficazes em vista de fins realizáveis. É assim, pois, que a prudência não é apenas um conhecimento de princípios gerais, pois tem também que levar em conta fatos particulares, uma vez que está envolvida com a ação, ocupando-se este de coisas particulares (ARISTÓTELES, 2009, p.188). Considera-se, portanto, o foco da phrónesis se voltar para o futuro, pois a decisão estará entrelaçada com o acontecer humano que é marcado pela contingência. 
A phrónesis se encontra no contexto prático situando no processo de ação humana. Dessa forma, há o processo de silogismo de Aristóteles tanto a premissa maior e quanto a premissa menor. Nesta situa o particular, em virtude de ser adquirido por meio da experiência, enquanto naquela apresenta o saber prudencial como universal e não contingente. Logo, o processo do silogismo proporciona a intermediação na relação entre universal e particular, ou seja, aponta a passagem de aproximação entre o homem e o mundo.

A justiça é a virtude perfeita por ser ela a prática efetiva da excelência moral perfeita, além do que é perfeita num grau especial, porque seu possuidor pode praticar sua virtude dirigindo-a aos outros e não apenas sozinho (ARISTÓTELES, 2009, p. 148). Dessa forma, a phrónesis se opõem ao saber predefinido marcado pelo caráter de objetividade do significado da excelência moral, tendo em mente que o saber prático é constituído a partir de cada fato específico da vida humana .

A formação do silogismo demanda o conhecimento do universal que visa assegurar um fim (bem supremo) e do conhecimento particular que está relacionado com a experiência e com o contingente, tendo em vista que a virtude moral assegura a retidão do fim a que visamos, enquanto a prudência garante a visão dos meios a serem utilizados para atingir esse fim (ARISTÓTELES, 2009, p. 196).

Nesse sentido, nos diz também MacIntyre:

Tal silogismo consiste em duas premissas: uma premissa inicial (frequentemente chamada equivocamente de premissa maior), através de cuja afirmação o agente declara qual bem está em questão ao agir ou não agir como deve; e uma segunda premissa (correspondentemente chamada de premissa menor), através de cuja afirmação o agente declara em que situação, uma vez que este bem está em questão, a ação é exigida. A conclusão chega a partir dessas premissas é a ação exigida (MACINTYRE, 2010, p. 144)

Vale destacar que no pensamento aristotélico, a ciência política ou a filosofia prática, apresenta o caráter do saber científico, com a pretensão universal e generalista; já a phrónesis, na medida em que se relaciona às ações humanas, não tem caráter de conhecimento científico, pois se relaciona com os fatos particulares, já que a ação a ser praticada é desta natureza contingencial (ARISTÓTELES, 2009).

Desse modo, a filosofia prática, apesar dos contornos práticos examinados, deve ser catalogada como uma virtude teórica, posto inserida na categoria do conhecimento científico, mas deverá ser considerado um conhecimento científico especial, que dá suporte ao desenvolvimento da phrónesis. Na sistematização, a diferença entre ciência política e a prudência: esta se preocupa com o contingente; aquela, com o fundamento da decisão em cada caso. Assim, o pensamento prático norteia a filosofia prática assim como a phrónesis (ENGELMANN, 2007). Este fato se conecta no pensamento de Aristóteles em razão do pensador ter como marca a presença da racionalidade ética de cunho teleológico que visa a busca da felicidade.

Agora, na recepção de Gadamer ao pensamento aristotélico notamos a aproximação do saber prático da phrónesis com a hermenêutica, é que a tarefa hermenêutica também é prática desde o início. Dito de outro modo, a aplicação não é apenas a parte final do processo da compreensão, mas está presente desde o início, pois 
tampouco aqui a aplicação consistia em relacionar algo geral e prévio com uma situação particular. O intérprete que se confronta com uma tradição procura aplicá-la a si mesmo (GADAMER, 2005) tudo indica que a consideração da phrónesis é a indicação da presença da tradição. Por isso, quando Gadamer refere que o intérprete aplica a tradição a si mesmo está requerendo sublinhar que esse ato é crítico, a saber, não é uma mera reprodução, mas uma aplicação crítica da tradição ao intérprete. Vale dizer, todo este contexto, onde o intérprete já está inserido desde sempre, condiciona a tarefa hermenêutica. E é sempre uma tarefa prática, motivo pelo qual a aplicação acaba sendo uma característica muito importante do trabalho do intérprete ao colocar em ação as possibilidades da phrónesis (SCHUCHMAN, 1979)

Enrico Berti (1997, p. 325) leciona que a variedade de experiência, a multiplicidade dos objetos defrontados, fazem, sim, com que o "sistema" aristotélico se articule e uma multiplicidade de partes relativamente autônomas uma em relação à outra e, no entanto, formando uma espécie de única e grande rede, com a qual se procura não aprisionar a realidade para dominá-la, mas fornecer um mapa para orientar-se nela, dar, em suma, um "sentido" a cada parte sua, sabendo que o sentido da parte depende sempre da posição que ela ocupa no todo, isto é, que o "texto" se compreende somente à luz do "contexto".

A concepção da filosofia prática, que busca justificar a phrohairesis, que nada mais é do que a tomada de uma decisão racional, encontra-se alicerçada na phrónesis, por representar a postura do sujeito frente à situação concreta. Assim, muito antes de estabelecer distinções entre ambas, Gadamer procurou aproximar a filosofia prática e a phrónesis, transformando a própria perspectiva dada por Aristóteles. Haja vista que, pelos delineamentos aristotélicos, a filosofia prática acabaria sendo um conhecimento científico, de cunho fortemente teórico. Gadamer, pelo contrário, caracterizou a filosofia prática como um conhecimento "científico", mas de contornos diferenciados, dada a sua interdependência com a "práxis", ou a decisão desenvolvida nos fatos concretos da vida (ENGELMANN, 2007, p. 125)

A filosofia prática e a hermenêutica filosófica não se voltam para estipular regras nos casos particulares situados no comportamento humanos, mas o de analisar os efeitos que a história projeta no ser. Nesse contexto, a hermenêutica filosófica não se encontra associada ao método, pois é levado em consideração que o indivíduo está imerso no fluxo da história, e neste plano de movimentação humana é encontrado o campo que o sujeito se identifica com a tradição que faz parte.

Com a aproximação da hermenêutica filosófica de Gadamer com o pensamento de Aristóteles referente à phrónesis abre a possibilita de a hermenêutica se tornar uma arte capacitada de elaborar, de completar de significado ou de aprimorar as normas gerais que deverão ser aplicadas nos casos particulares.

A partir da perspectiva da hermenêutica filosófica, as análises jurisprudenciais das decisões do STF têm que ser realizadas mediante o procedimento de perguntas e respostas. A questão, a saber, é denunciar os limites 
estreito e pouco fecundos da concepção de que devemos extrair um significa oculto do conteúdo da fundamentação judicial nos moldes da hermenêutica tradicional que lançava mão de métodos interpretativos a fim de que o texto se tornasse mais claro para o intérprete. Na proposta da hermenêutica filosófica, fazer perguntas diante do conteúdo previamente exposto das decisões jurídicas e as repostas oferecidas não serão arbitrárias, pois estarão situadas de acordo com a tradição que o intérprete faz parte e a qual justifica a sua pré-compreensão. No entanto, é importante lembrar a relação circular formada entre perguntas e respostas sempre excluirá possibilidades no processo interpretativo.

A compreensão é o poder de captar as possibilidades que cada um tem de ser, no contexto do mundo vital em que cada um de nós existe. (...) A compreensão não se concebe como algo que possua mas antes como um modo ou elemento do ser-no-mundo. Não é uma entidade no mundo, antes é a estrutura do ser que torna possível o exercício atual da compreensão a um nível empírico. A compreensão é a base de toda interpretação; é a contemporânea da nossa existência e está presente em todo o ato de interpretação (PALMER, 1996, p. 135).

Assim, na prática humana, o que Aristóteles chama de éthos tem importância fundamental (GADAMER, 2009a, p.162). Nesse contexto, a phrónesis surge como virtude da hermenêutica fundamental de Gadamer, em razão da prudência ser responsável pela concessão da atitude ética na formulação do resultado hermenêutico. Assim, na dialética de pergunta e de resposta na relação entre realidade-interpretação há a contemplação do respeito à pluralidade, pois nesta corre a projeção aproximativa da compreensão com a consciência histórica como elementos efetivos da hermenêutica filosófica.

Numa medida mais larga, o preconceito, como antecipação da experiência humana, atesta o vínculo com a tradição de que somos partícipes. É o que Gadamer chama de consciência das histórias dos efeitos, o que possibilita o entender-se e o desentender-se uns com os outros, a imensa, penetrante conversação humana a sua tradutibilidade de universo linguístico para universo linguístico. Parece que estamos a ouvir a ressonância do ensinamento de Heidegger extraído de Hölderlin: nós somos um diálogo (NUNES, 2011, p. 274-275).

No plano ético, para que possamos agir temos de nos compreender como parte de uma história cujo entendimento implica em compreender quem somos e quem queremos ser. Nesse processo de entendimento, é importante saber que o nosso ser é determinado pelo fluxo da história que nos transmite no interior de uma tradição o qual pertencemos e que nos lega nossos pré-conceitos, cujo conjunto forma o ponto de partida para o entendimento (GADAMER, 2005).

É nesse diapasão que as decisões do STF referidas ao longo desse texto não devem ser lidas como exercício da atividade subsuntiva em uma operação lógico-formal de aplicação da norma ao fato subsumido. Bem longe disso, a norma poder dizer muitas coisas, dentre as quais as antípodas das próprias decisões proferidas nos casos em análise. Assim, por ilustração, a decisão sobre a constitucionalidade da lei de biosssegurança quanto à utilização de embriões para pesquisa científica entendeu que o direito à vida garantido pela Constituição não 
alcança os embriões, assumindo que não possuem ainda estatuto pessoal. A decisão hipotética que lhe fosse absolutamente contrária, qual seja, a inconstitucionalidade da Lei e a consequente impossibilidade do uso de embriões nas pesquisas, igualmente estaria baseada no mesmo direito constitucionalmente expresso à vida. O que interessa, portanto, é muito menos o que diz a norma e muito mais o que o intérprete diz sobre o que diz a norma.

E nesse arco compreende-se novamente a afirmação situacional do intérprete e as perguntas sobre quais os valores presentes nas escolhas dos agentes morais que lidam com a norma e aos quais ela é destinada. E isso não escapou aos ministros nas suas decisões, pois a sociedade e os efeitos das decisões acerca dos fundamentos implicados estavam como elementos recorrentes, ainda que eventualmente tenham sido considerados de maneira criticável.

\section{A HERMENÊUTICA JURÍDICA É CAPAZ DE REALIZAR A LEITURA ÉTICA DA CONSTITUIÇÃO POR MEIO DA ANÁLISE DO CONCEITO DE BEM COMUM}

A hermenêutica se situa dentro da tradição a qual nos revela como sendo seres históricos, éticos e políticos, o que conduz ao pensamento de Gadamer de que a filosofia prática sempre está relacionada com a práxis dos agentes, tendo em vista que:

Se o próprio núcleo do problema hermenêutico é que a tradição como tal tem de ser
entendida de uma maneira diferente, então - visto sob ponto de vista lógico - trata-se de uma
relação entre o geral e o particular. Compreender é então um caso da aplicação de algo geral
a uma situação concreta e particular. Com isso ganha especial relevância para nós a ética
aristotélica, de que já mencionamos nas nossas consideraçães introdutórias à teoria das
ciências do espírito. É verdade que Aristóteles não aborda o problema do círculo
hermenêutico e nem sua dimensão histórica, mas trata somente da apreciação correta do
papel que a razão deve desempenhar na atuação ética. Mas isso precisamente que nos
interessa aqui, mas que são determinados por este e que são determinantes para este ser
(GADAMER, 2005).

Segundo Gadamer, a experiência hermenêutica tem a ver com a tradição, sendo que esta deve chegar pela experiência. Porém, explica que a tradição não é simplesmente um acontecer que se pode conhecer e dominar pela experiência, mas é linguagem, isto é, fala por si mesma como faz um tu. Embora a tradição não confunda com o tu (SILVA, 2014), a nossa experiência de compreensão da tradição pode ser analisada a partir da experiência de compreensão do outro, uma vez que o intérprete que compreende sua situação no mundo trava um diálogo com a tradição assim como os demais intérpretes com que ele convive numa mesma situação histórica. Assim, tanto tradição como o tu não são objetos, mas verdadeiros companheiros de comunicação a que todos estamos vinculados (GADAMER, 2005).

A reconciliação consigo mesmo é possível por meio da experiência da alteridade, por isso o Outro é fundamental para que laços genuínos de amizade possam ser criados. Os laços, vínculos ou ligações com o Outro ou para com o Outro criam o sentido obrigatório (GADAMER, 2009b) na experiência hermenêutica dos 
indivíduos situados historicamente.

Gadamer confia numa ordem moral (um ethos), onde se encontra o fundamento das instituições, por exemplo, o estado: não só na antiguidade, chamada cidade-estado, mas também o moderno. Pois, em ambos se repousam sobre a mesma e inevitável condição da solidariedade que é elemento comum e é entendida a partir de tomadas de decisões comuns. Aparentemente, Gadamer pensa algo como o conceito grego de amizade para servir como articulação da vida social ${ }^{10}$ (tradução nossa) (SANCHO, 2010, p. 170).

O conceito de amizade em Gadamer possui o seu desdobramento na solidariedade autêntica por esta ser uma promessa de pagamento de amizade, ou seja, pode-se exigir uma ação concreta da comunidade política tendo em vista a busca do telos do bem-estar do outro na identificação do $t u$, o qual é projetado por meio da consciência histórica efeitual, em razão desta ser o aporte que sinaliza como condição de possibilidade para buscar a abertura da compreensão mútua entre os cidadãos no aspecto ético e político. Este fato permite que no Estado Democrático de Direito o intérprete por ser um Ser histórico, ele possa interagir e modificá-la ao formular questionamentos voltados para as decisões políticas tomadas do passado para compreendê-lo e avaliá-lo a fim de iluminar as suas decisões do presente.

A filosofia moral cabe buscar reconciliar um fato particular ou uma escolha moral individual com os princípios universais de uma sociedade. Ética não deve ser compreendida como uma simples questão de aplicação de regras e princípios universais e necessários, isto é, válidos em qualquer situação, mas, sim, como uma espécie de visão conformadora acerca da vida boa ou justa, com intrínseca relação com a práxis (MATOS, 2012, p.93).

A filosofia deixa então de constituir-se em conhecimento fechado, onde se propaga uma reflexão abstrata e que procura se bastar a si própria, para voltar-se para a realidade social objetiva. Recupera, em certo sentido, as suas origens na Grécia Clássica, quando o homem abandonou progressivamente a explicação dos fenômenos naturais e a legitimação do poder político, como reflexo do mundo dos deuses mitológicos, substituindo esse paradigma pelo logos, o discurso racional como forma de formulação do entendimento do cosmos e justificação do Estado e do Direito (BARRETTO, 2012, p. 5939).

A atividade do juiz, via de regra, não se encontra mais plenamente restringido pelo método da subsunção legal, tendo em vista que podemos assinalar no Direito brasileiro, decisões jurídicas voltadas para o campo da política como expressão da ética. Retirar a razão prática é extrair também as influências da sua tradição, da sua carga conceitual, da sua carga semântica de leitura de bem comum e de boa vida (kaion). Resumindo, é necessário contrapor a razão teórica da ciência moderna das ideias positivistas e a razão prática da hermenêutica.

Por causa da objetivação da técnica, do século XX, ocorreu também a despolitização do sentido amplo

\footnotetext{
${ }^{10}$ Gadamer confia en un orden moral (um êthos), que es en el que descansan las instituciones, por ejemplo: el estado; no sólo el antiguo, la llamada ciudad-estado, sino también el moderno. Pues ambos descansan sobre la misma e inevitable condición básica: la condición de la solidaridad, que es esse elemento en común y sobreentendido desde el cual resulta posibile tomar decisiones en la vida moral, social y politica, decisiones comunes. Al parecer, Gadamer piensa en algo semejante al concepto griego de la amistad que servía para articular la vida social.
} 
da palavra política como era adotada pela tradição antiga, a qual foi posteriormente recepcionada por Santo Tomás de Aquino. Estamos tratando aqui a polis como uma forma orgânica em que nós indivíduos, enquanto cidadãos, somos capazes de deliberar a condução da vida boa. O elemento moral é indissociável nessa concepção antiga de polis. A cidade-estado é sempre um lugar de possibilidade de buscar a realização de felicidade (eudaimonia).

As exigências de razoabilidade prática e as leis naturais se situam na tradição, requerendo que as decisões (phrónimos) da magistratura brasileira estejam atentos a esses dois elementos, ainda hoje pouco repercutidos na teoria do direito, a fim de que possam atingir a realização adequada na busca das necessidades humanas básicas que estão relacionadas com o conceito de bem comum.

Na razoabilidade prática, há o desenvolvimento da promoção do bem comum nas práticas realizadas na vida em comunidade, tendo em vista que esta é iluminada pela prática de amizade pelo fato do bem comum está vinculada a concretização do individual, mas voltada a responsabilidade do coletivo. Na teoria do direito contemporânea, Finnis (2007b) se refere ao fator ou conjunto de fatores que, presentes como considerações no raciocínio de uma pessoa, dariam um sentido a, ou uma razão para, sua colaboração com outros e dariam a si mesmo, desde o ponto de vista dos outros, uma razão para sua colaboração entre eles mesmos e com essa pessoa, sendo um dos poucos autores a caminhar em uma contracorrente em direção a toda demais teoria do direito que assume como dada a despolitização do direito e seu caráter eminentemente técnico e aplicativo.

O bem comum visa o bem-estar tanto do indivíduo, quanto da coletividade na projeção de alcançar atender as necessidades básicas do homem. Podemos fazer a revisitação histórica desta noção em Aristóteles (1999) ao afirmar que a observação mostra que cada Estado é uma comunidade estabelecida com alguma boa finalidade, uma vez que todos sempre agem de modo a obter o que acham bom. Mas, se todo as comunidades almejam o bem, o Estado ou comunidade política, que é a forma mais elevada de comunidade e engloba tudo o mais, objetiva o bem nas maiores proporções e excelência possível.

É importante notar que a caracterização de bem comum caminha lado a lado com a ideia de justiça. Isso ocorre, pois um dos elementos da justiça é alteridade, na medida em que se trata de uma relação não-pessoal, mas intersubjetiva (ENGELMANN, 2007). Assim, é correto dizer que as exigências da justiça são as implicações concretas da exigência básica da razoabilidade prática segundo qual deve-se favorecer e promover o bem comum de suas próprias comunidades (FINNIS, 2007b). Resta evidenciar a questão interpessoal da justiça e da noção de bem comum. Trata-se de uma busca a ser empreendida pelo indivíduo associado aos seus semelhantes.

Santo Tomás de Aquino vai demonstrar que a ordem política só pode se fundamentar na autoridade. Tendo em vista que a autoridade em si sempre revela um fundamento que será de ordem natural. A sua preocupação consiste em que a teoria seja capaz de revelar o fundamento das coisas. Ao redescobri-lo, a ordem 
normativa é capaz de se integrar e de fazer a reabilitação do seu sentido valorativo. Interessa saber que a leitura política da sociedade só pode ser feita a partir da concepção de que há elementos morais que são capazes de fundamentá-la.

Os liberais opõem a noção de direitos humanos ao conceito de bem comum. Os direitos humanos representariam um limite ao bem comum. Porém, se o bem comum é o bem de todos, como afirma a ética tomista, o conceito de direitos humanos apenas expressa os contornos do bem comum, os distintos aspectos do bem-estar individual na comunidade (FINNIS, 2007b).

A finalidade da vida em comunidade é a autorrealização, a vida boa. $\mathrm{O}$ bem da comunidade, o bem comum, é alcançado quando os membros da comunidade possuem as condições comunitárias de realização da vida boa. Os direitos humanos como aspecto da vida boa são a articulação do conteúdo do bem comum, eles revelam a natureza distributiva do bem comum como bem de todos: o bem comum só existe na medida de em que é partilhado por todos. Os direitos humanos são a parte que cabe a cada um no bem comum. Sem o conceito de direitos humanos, perde-se um instrumento conceitual valioso para determinar o conteúdo concreto da participação de cada membro da comunidade, o bem comum, ou seja, daquilo que é devido a cada um na partilha do bem comum (BARZOTTO, 2010, p. 47).

Tomás de Aquino (2002, p. 18) assinala que quanto mais se separa do bem comum, tanto mais injusto será o regime político. Mais se distancia do bem comum a oligarquia, pelo fato desta buscar o bem de alguns poucos; ou em certa medida a democracia, em razão de buscar o bem de muitos e não de todos; e no entanto se distancia ainda mais do bem comum a tirania que se encontra comprometida exclusivamente no bem de uma pessoa $^{11}$ (tradução nossa).

Ainda, Tomás de Aquino (2002, p. 24) observa que o bem comum não se encontra no cuidado de uma pessoa e não pode ser contemplado como algo estranho, mas cada pessoa deve conceber o bem comum como sendo algo próprio de todos ${ }^{12}$ (tradução nossa).

Cada membro, ao afirmar seu direito, visa especificar qual é a sua parte no bem comum. Sem o conceito de direitos humanos, corre-se o risco de que o bem comum seja identificado na prática com o bem de uma classe, do Estado, do partido ou de um grupo. Os direitos humanos trazem o bem comum do céu das abstrações coletivas para o chão da vida concreta dos seres humanos (BARZOTTO, 2010, p. 47).

A preocupação teológica aqui tratada de Santo Tomás de Aquino não é a de firmar a posição do dogma, mas a preocupação teológica é de investigação da verdade de natureza. Esse elemento nós perdemos

\footnotetext{
${ }^{11}$ Luego cuanto más se separe del bien común, tanto más injusto será el régimen. Más se separa del bien común la oligarquia, en la que se busca el bien de unos pocos, que la democracia, en la que se busca el bien de muchos; y todavia se separa más del bien común la tiranía, en la que se busca exclusivamente el bien de uno.
} 
completamente. Talvez o que tenhamos conscientemente ou não descoberto na idade moderna que a busca do fundamento valorativo nunca vai se contentar com o plano do mero acordo entre vontades.

Na perspectiva de Tomás de Aquino (2002, p. 66), também cabe como tarefa para governo a de manter o cidadão e de preservá-lo de acordo com o fim em que o Estado foi fundado. Logo, não poderá ser conhecida completamente a tarefa do governo se ignorado a razão de sua formação. A razão da formação de um "Estado" tem que se tomar, como exemplo, a formação do mundo, em que neste, no princípio, se considerada a produção de todas as coisas do mundo e depois a sua distinta gestão nas diferentes partes do mundo ${ }^{13}$ (tradução nossa).

Em outras palavras, há uma necessária dependência do conhecimento filosófico com a formulação e a legitimação dos fundamentos do estado democrático de direito no século XXI. A prática do estado democrático de direito pressupõe, portanto, o conhecimento dos fundamentos e valores, conceituados e analisados na filosofia, que se constituem nos alicerces morais e políticos, que possibilitam a convivência na sociedade humana e asseguram a seiva necessária para a aplicação do direito (BARRETTO, 2012, p. 5940).

Quando referimos lei natural surge a dúvida sobre o conteúdo e a extensão dos termos leie natural.John Finnis, a esse respeito, esclarece que o termo lei não significa o mesmo que os comandos ou as ordens oriundas de uma autoridade superior, quando facilmente poderia ser confundida com a ideia de lei para o positivismo jurídico. Pelo contrário, a concepção de lei aqui empregada remete aos critérios da boa escolha, a critérios que são normativos (ou seja, racionalmente compulsórios e obrigatórios) por serem verdadeiros, e não é razoável escolher de outra maneira senão segundo esses critérios (FINNIS, 2003). Embora se possa dizer que esses critérios também sejam obrigatórios, até para justificar de modo racional e aceitável uma determinada decisão, a força dessa ordem é diferente, dado que oriunda da tradição e não dependente do voluntarismo de qualquer espécie de autoridade (ENGELMANN, 2007).

Para Finnis (2007a, p.104), importaria em reconhecer que a teoria do direito natural está significantemente menos interessada, do que as teorias juspositivistas contemporâneas, em estabelecer os limites e conteúdo precisos do direito de nossa comunidade originado (positivado, puramente positivo) fático socialmente? Realmente não. Isto em razão de que:

i. As teorias juspositivistas contemporâneas abandonaram a tese dos positivistas jurídicos "clássicos" tais como Bentham, de que os juízes e cidadãos igualmente deveriam (como uma questão de obrigação político-moral) condescender com o direito positivo de sua comunidade;

ii. As teorias do direito natural sustentam tão fortemente, como qualquer outra teoria

\footnotetext{
${ }^{12}$ Observan que el bien común no se encuentra al cuidado de uno, no contemplan ese bien común como algo ajeno, sino que cada uno tende a él como algo próprio.

${ }^{13}$ También pertence a la tarea de gobierno conservar lo governado y usar de ello conforme al fin para el que fue fundado. Luego no podrá conocerse plenamente la tarea de gobierno si se ignora la razón de su formación. La razón de la formación de un reino hay que tomarla del ejemplo de la formación del mundo, en el que en principio se considera la producción de las mismas cosas y después la distinta ordenación de las partes del orbe.
} 
positivista, que julgamentos adequados e legítimos dão prioridade a uma atenção consciente e técnica às fontes fático-sociais e às regras e princípios com pedigree ${ }^{14}$ de tais fontes, rejeitando-os apenas se e na extensão em que eles são ",muitos iníquos para serem aplicados", e costuram a nova regra resultante unindo-a da forma mais coerentemente possível com todas as outras (não muito iníquas) doutrinas, regras e princípios do sistema jurídico particular no qual o juiz tem jurisdição.

Desse modo, os princípios da lei natural e as exigências da razoabilidade prática desenvolvidas por John Finnis, herdeiro do pensamento tomista de bem comum, fazem parte e justificam a pré-compreensão do intérprete, estará aberto o caminho para o seu ingresso no círculo hermenêutico e, portanto, reforçar os objetivos preconizados pelo Estado Democrático de Direito (ENGELMANN, 2007).

\section{CONCLUSÃO}

$\mathrm{Na}$ atualidade o debate jurídico se encontra incontornavelmente atado à realização do Estado Democrático de Direito. Neste soa como sendo algo absurdo remeter a perspectiva mais estrita do positivismo jurídico concebido na primeira metade do século XX, aos moldes da Teoria Pura de Hans Kelsen, pois este modelo de legalismo sofreu duras críticas por desconectar a ética com o Direito, afastando-o da realidade.

Enquanto que o contexto de assunção do positivismo normativista insere-se no debate científico em torno do neokantismo de Marburgo e da afirmação metódica das ciências humanas em face das ciências da natureza, os problemas suscitados pelo perído entre-guerras e a transição do pós-guerra, tais como a crise das democracias representativas, a internacionalização dos direitos pela ampliação de uma concepção mais ampla dos direitos fundamentais e humanos, fazem emergir no pensamento jurídico atual a imperiosa análise do fundamento ético da ordem constitucional e transconstitucional. Esta característica aponta, negativamente, para a impossibilidade e impertinência da objetivação das ciências humanas por meio de métodos das ciências naturais. Na esfera positiva, trata-se do desvelamento dos seus principais elementos, tais como: a historicidade, temporalidade e preconceitos sem o que ela não terá chance de haver-se com a leitura da realidade.

A Teoria do Direito contemporânea esteve diretamente relacionada a alguns traços de pressupostos positivistas que problematizam o ato de interpretar. Referimo-nos às características do neokantismo de Marburgo, na Alemanha, a qual visou redefinir o conceito de conhecimento, no sentido preciso de reflexão sobre os fundamentos, os métodos e os limites da ciência. Para o neocriticismo a filosofia deve voltar a ser o que era com Kant: análise das condiçôes de validade da ciência e dos outros produtos humanos, como a moral, a arte ou religião. Disso torna-se clara a razão pela qual os neokantianos propõem uma filosofia dominada por problemas

\footnotetext{
${ }^{14}$ Hart defende o que Dworkin chama de uma teoria do "pedigree" da validade das regras jurídicas. Segundo essa teoria, os juízes identificam e distinguem regras legais válidas de outras regras (por exemplo, regras de etiqueta ou regras morais), ao verificar de onde tais regras se originam. As regras legais válidas têm o pedigree certo - elas derivam de fontes aceitas, como: leis, costumes, precedentes judiciais, etc.
} 
gnosiológicos ao invés de problemas empírico-factuais ou metafísicos (REALE, 2006, p. 22).

O problema consiste na ênfase da aplicação da técnica por meio de métodos interpretativos que visam uma objetividade para extrair o conhecimento do próprio texto, o que aponta para a mitigação da falta de transparência hermenêutica não só da consciência do horizonte do interprete de fornecer, como também de se encontrar numa fusão do horizonte com o texto.

O positivismo jurídico considera a interpretação como uma subsunção lógica ou um ato cognitivo e, daí, impregnada de atemporalidade. Tendo em vista que a transformação conceitual se encontra entre cognição e compreensão, pois a hermenêutica filosófica pressupõe historicidade do objeto interpretado que não é mais objeto, mas um sujeito porque é um diálogo intersubjetivo com o constituinte a partir da constituição. Esse diálogo tanto permite a expressão da Constituição, como a condiciona a ouvir-nos.

Daí o artigo ter procurado demonstrar pela via hermenêutica tais limites da interpretação enquanto técnica, tendo diante de si os desafios éticos propostos pelo Estado democrático de Direito. O principal dentre tais desafios é o de realizar o objetivo de "boa vida" ou "justiça" que está na base do que justificaria os esforços que implica viver em sociedade, ter em conta sempre a limitação que os direitos impõem diante do direito de outros, lidar com pluralismo, multiculturalismo, equilibrar politicamente a regra da maioria com a preservação da voz das minorias, etc. Segundo o que entendemos no presente texto, esses são desafios formidáveis que não podem ser enfrentados sem uma noção de fim e não apenas de meios. De conteúdo do direito, portanto, e não somente de forma.

É esse argumento que abre o artigo para a discussão da concepção ancestral de "bem comum" e sua tradição entre o tomismo e a analítica do direito contemporâneo em John Finnis. Assumimos que o conceito retorna para demonstrar sua atualidade e funcionalidade na análise de grande parte dos problemas do Estado democrático de direito atual para os quais a interpretação enquanto mera técnica ou concepções herméticas de ordenamento jurídico não conseguem dar respostas convincentes.

Em um horizonte teórico pós-metódico assumimos o argumento de que o direito pode ganhar muito ao voltar-se para uma tradição prudencial que foi perdendo espaço para o sonho quimérico da exatidão e dos sistemas formais.

\title{
PHILOSOPHICAL HERMENEUTICS AND THE MORAL FUNDAMENTALS OF THE CONSTITUTIONAL ORDER IN THE DEMOCRATIC STATE OF LAW
}

\author{
Abstract \\ Jurisprudential analysis, based on the references of philosophical hermeneutics, on the concept of the common \\ good based on the judgments given by STF, in order to find out what are the Foundations of the Constitutional \\ Order in the Democratic State of Law, according to the Brazilian Constitutional Court. This task requires
}


examining the writings contained in the work of Truth and Method and also in the writings subsequent to the Truth and Method of Gadamer and to investigate the concept of the common good from St. Thomas Aquinas and John Finnis. Finally, to analyze the presuppositions of the theory of the concepts involved in the hermeneutic discussion, namely, nominalism, constructivism, realism and idealism. The questioning of interpretation as a logical-subsuntive technique is performed by pointing out that it is fundamental for hermeneutics to understand certain elements such as historicity, temporality and prejudice so that the condition of possibility for the intersubjective dialogue between the interpreter and the Constitution. Thus, we seek to reinsert ethical-evaluative elements in constitutional interpretation, but demonstrating that philosophical hermeneutics is capable of providing solid references that do not appeal to relativism and the solipsism of the interpreter.

Keywords: Hermeneutics; Common Good; Constitutional Order; Democratic State; Natural law; Legal positivism; Jurisprudence.

\section{REFERENCIAS}

ARISTÓTELES. Ética a Nicômaco. Trad. Edson Bini. 3a ed. São Paulo: Edipro, 2009.

Política. Trad. Therezinha Monteiro Deutsch e Baby Abrão. São Paulo: Nova Cultural, 1999.

BARRETTO, Vicente de Paulo. Filosofia, Direito e Estado Democrático de Direito. Vol. 10. Coimbra: Revista do Instituto de Direito Brasileiro, 2012.

2013.

O Fetiche dos Direitos Humanos e outros Temas. 2a ed. rev. e ampl. Porto Alegre: Livraria do Advogado,

BARRETTO, Vicente de Paulo; CULLETON, Alfredo. Raízes Filosóficas do Estado Democrático de Direito ou Porque Estudar Filosofia do Direito. vol. 1, n. 5. Porto Alegre: Revista do Instituto de Hermenêutica Jurídica, 2007

BARZOTTO, Luis Fernando. Filosofia do Direito: os conceitos fundamentais e a tradição jusnaturalista. Porto Alegre: Livraria do Advogado, 2010.

BENEDITO, Nunes. Ensaios Filosóficos. In: Victor Sales Pinheiro (org). São Paulo: Editora WMF Martins Fontes, 2011.

BERTI, Enrico. Aristóteles no Século XX Trad. Dion Davi Macedo. São Paulo: Loyola, 1997.

COSTA, Paulo Sérgio Weyl. Autonomia e Norma Jurídica. Porto Alegre: Livraria dos Advogados 2008.

ENGELMANN, Wilson. Direito Natural, Ética e Hermenêutica. Porto Alegre: Livraria do Advogado, 2007.

FERREIRA FILHO, Manoel Gonçalves. Curso de Direito Constitucional. São Paulo: Saraiva, 2001.

FINNIS, John. Direito Natural em Tomás de Aquino: sua reinserção no contexto do juspositivismo analítico. Trad. Leandro Cordioli. rev. Elton Somensi de Oliveira. Porto Alegre: Sergio Antonio Fabris, 2007a.

Lei Natural e Direitos Naturais. Trad. Leila Mendes. Rio Grande do Sul: UNISINOS, 2007b.

Lei natural. Por eu chamar de lei? Por que dizê-la natural? Trad. Magda Lopes. In: CANTO-SPERBER, Monique (org.). Dicionário de ética e filosofia moral. São Leopoldo: Unisinos, 2003. 
GADAMER, Hans-Georg. A Ideia do Bem entre Platão e Aristóteles. Trad. Lívio Cruz Romão. São Paulo: Editora WMF Martins Fontes, 2009a.

Verdade e Método I: traços fundamentais de uma hermenêutica filosófica. Trad. Flávio Meurer. $7^{a}$ ed. Vozes: Petrópolis, 2005.

Verdade e Método II: traços fundamentais de uma hermenêutica filosófica. Trad. Enio Paulo Giachini. rev. Marcia Sá Cavalcante Schuback. 2a ed. Vozes: Petrópolis, 2004.

Friendship and Solidarity. Research in Phenemonology, Leiden, vol. 39, issue 1, $2009 \mathrm{~b}$.

JACQUES, Paulino. Curso de Direito Constitucional. 10aed. Rio de Janeiro:Forense, 1957.

MACTINTYRE, Alasdair. Justiça de quem? Qual Racionalidade? Trad. Marcelo Pimenta Marques. $4^{a}$ ed. São Paulo: Loyola, 2010.

MASCARENHAS, Diego Fonseca. A Determinação da Tutela Jurisdicional da Vida Humana. vol. 2. Revista eletrônica Saber Jurídico, 201 la.

Lei e Liberdade na ADPF 130: uma leitura da decisão a partir de Hannah Arendt. 2013. (156 fls.). Dissertação (Mestrado) - Universidade Federal do Pará, Instituto de Ciências Jurídicas, Programa de PósGraduação em Direito. Belém, 2013.

Participação da Esfera Pública como Requisito de Ilegitimidade em Decisões Judiciais em Sede do Controle de Constitucionalidade: exame do caso da ADIn 3.10, impetrada contra a lei de biossegurança. In.: Bárbara Lou da C. Veloso Dias; Ana Darwich (orgs.). Direito e Democracia: estudos sobre o ativismo judicial. São Paulo: Método, 2011 b.

MASCARENHAS, Diego Fonseca; COSTA, Paulo Sérgio Weyl Albuquerque. A Revogação da Lei de Imprensa como Caminho para (Des)construção da Liberdade. In: MAÚES, Antônio; BACELAR, Jeferson; COSTA, Paulo (orgs.). A Jurisprudência Constitucional Revisitada: uma homenagem da advocacia paraense aos 25 anos da Constituição Federal. Rio de Janeiro: LMJ Mundo Jurídico, 2014.

MATOS, Saulo Monteiro. O Conceito de Direito na Filosofia Moral Gadameriana. Rio Grande do Sul: RECHTD, 2012.

PALMER, Richard E. Hermenêutica. Trad. Maria Luísa Ribeiro Ferreira. Lisboa: Edições 70, 1996.

PATTON, Michael Q. Qualitative Evaluation Methods. Beverly Hills, CA: Sage, 1980.

REALE, Giovanni. História da filosofia 6: de Nietzsche a Escola de Frankfurt. Tradução: Ivo Storniolo. São Paulo: Paulus, 2006.

SANCHO. Jesús Conill. Ética Hermenéutica: crítica desde la facticidad. Madrid: Tecnos, 2010.

SILVA, José. Apontamentos Sobre a Experiência do Outro, Amizade e Solidarieadade em H.G.Gadamer. v.6. Santa Catarina: Revista Peri, 2014.

SCHUCHMAN, Paul. Aristotle’s Phrónesis and Gadamer's Hermeneutics. In: Philosophy Today, New York: St. John's University Library, n.23, 1979.

SUPREMO TRIBUNAL FEDERAL. ADPF n. ${ }^{\circ}$ 130. 2009. Disponível em: 
<http://www.stf.jus.br/portal/geral/verPdfPaginado.asp?id=334823\&tipo=TP\&descricao=ADPF\%2F130>. Acesso em: 22 nov. 2016.

SUPREMO TRIBUNAL FEDERAL. ADIn n. ${ }^{\circ}$ 3.510. 2005. Disponível em: < http://www.stf.jus.br/portal/geral/verPdfPaginado.asp?id=61 1723\&tipo=AC\&descricao=Inteiro\%20Teor\%20 ADI\%20/\%203510>. Acesso em: 05 out. 2016.

SUPREMO TRIBUNAL FEDERAL. ADPF n. ${ }^{\circ}$ 132. 2011. Disponível em: < http://www.stf.jus.br/portal/geral/verPdfPaginado.asp?id=628633\&tipo=AC\&descricao=Inteiro\%20Teor\% 20 ADPF\%20/\%20132>. Acesso em: 03 set. 2016.

SUPREMO TRIBUNAL FEDERAL. ADIn n. ${ }^{\circ}$ 3.330. 2012. Disponível em: <http://www.stf.jus.br/portal/geral/verPdfPaginado.asp?id=35301 12\&tipo=TP\&descricao=Inteiro\%20Teor\%2 0ADI\%20/\%203330>. Acesso em: 01 set. 2016.

TOMÁS DE AQUINO. La Monarquia. 3a ed. Madrid: Tecnos, 2002.

Trabalho enviado em 13 de março de 2017.

Aceito em 04 de julho de 2017. 